\title{
Pilot workload and fatigue on short-haul routes: an evaluation supported by instantaneous self- assessment and ethnography
}

\section{Simon Ashley Bennett}

To cite this article: Simon Ashley Bennett (2016): Pilot workload and fatigue on short-haul routes: an evaluation supported by instantaneous self-assessment and ethnography, Journal of Risk Research, DOI: 10.1080/13669877.2016.1235603

To link to this article: http://dx.doi.org/10.1080/13669877.2016.1235603

曲 Published online: 24 Oct 2016.

Submit your article to this journal $\widetilde{ }$

Џ Article views: 130

Q View related articles $\widetilde{ }$

View Crossmark data \lceil 


\title{
Pilot workload and fatigue on short-haul routes: an evaluation supported by instantaneous self-assessment and ethnography
}

\author{
Simon Ashley Bennett* \\ Civil Safety and Security Unit, School of Management, University of Leicester, Leicester, UK
}

(Received 27 February 2016; final version received 19 July 2016)

\begin{abstract}
In the context of claims that the European Aviation Safety Agency's flight and duty- time regulations pose a threat to safety, pilot workload and fatigue were assessed on two short-haul routes using a mixed-methods approach. Data produced by the US Air Force School of Aerospace Medicine Crew Status Survey (CSS) showed that pilots rarely assessed workload and fatigue to be high-risk. Data produced by an ethnographic study somewhat contradicted the CSS findings, with some pilots claiming to be fatigued. The combined data suggested a correlation between both workload and fatigue and aviation system dynamics such as airspace manoeuvring restrictions, especially in the vicinity of busy airports. The research presented an opportunity to test claims made for the CSS, specifically that it is "easily understood, easy to administer and minimally intrusive'. Missing forms and errors suggest that it is not as reliable a research instrument as proponents suggest, although contextual factors may have served to reduce the volume and quality of data. It is concluded that a pre-survey, systems-thinking-informed evaluation of the host airline would suggest ways of improving buy-in.
\end{abstract}

Keywords: pilots; survey; workload; fatigue; short-haul; flight-and-duty-time regulations

\section{The research}

Conducted over two periods (14 June-31 July 2015, and 1 September-16 October, 2015), the research asked pilots to self-assess workload and fatigue on two commercial air routes, Birmingham, UK, to Niece (BHX-NCE-BHX) and Birmingham, UK, to Palma (BHX-PMI-BHX). To avoid overburdening pilots on these potentially high-workload routes, a simple research instrument was required. Charlton's (2008, 109-112) claims for the US Air Force School of Aerospace Medicine Crew Status Survey (CSS) prompted its selection: '[The CSS] was designed to be easily understood by the test participants, easy to administer and complete in the field ... The survey can be completed very quickly ... and thus produces little disruption'. To understand the reality of operating the routes the author made 12 jump-seat observation flights ${ }^{1}$ (a total of 24 sectors) during which he took notes and encouraged flight crew to complete the CSS (renamed the Workload-and-Fatigue Record, abbreviated to WorkFat). ${ }^{2}$

\footnotetext{
*Email:sab22@le.ac.uk
} 
In the context of claims that the European Aviation Safety Agency's (EASA's) flight and duty- time regulations pose a threat to flight safety (Bennett 2014), and of the proliferation of work-intensive short-haul routes, the research assessed levels of flight crew workload and fatigue on two intra-European routes. As the research unfolded, the opportunity arose to test Charlton's claims for the CSS, which is critiqued in the tradition of reflective practice (Dewey 1933; Schön 1983; Bolton 2010).

The degree to which workload affects performance is unclear (Hockey 2002). Impact is mediated by knowledge, experience, innate ability, fatigue, environmental conditions, required standards and other factors (Maurino et al. 1998; Campbell and Bagshaw 1999; Dekker 2007). It is possible that overburdened pilots may lose situation awareness. They may obsess about relatively unimportant matters (coning of attention). In a laboratory experiment with young, low-hours (10-300 h flight-time) student pilots, Morris and Leung $(2006,1595)$ noted 'high prioritisation error rates associated with increased mental workloads'. They also found that 'medium and high mental workload environments severely impacted on an individual's ability to listen [to], comprehend and respond to auditory messages' [my emphasis] (Morris and Leung 2006, 1595). Green et al. (1996, 46-47) note: 'At extremely high levels of workload (overload), important information may be missed, due to the narrowing or focusing of attention onto only one aspect of the task'.

Those subjected to high workloads may experience temporal distortion (a few minutes may seem like hours and an hour may seem like a few minutes) (Smith 2012). They may revert to learned behaviours inappropriate to their current situation:

$[\mathrm{U}]$ nder stress, behaviour may regress to the earliest learnt, such as operating a control or selector in a manner which would have been appropriate to the previous type of aircraft flown, but not the current one. (Campbell and Bagshaw 1999, 134)

While pilots train for high-workload, high-stress episodes, simulation can only approximate reality. Dekker $(2007,6)$ argues that pilots' foreknowledge of the simulation session's adverse event '[makes] the unexpected less unexpected'. He asks: How good a test is an expected, unexpected event? The link between fatigue and performance is better understood. Fatigue provokes error (Battelle Memorial Institute 1998; Campbell and Bagshaw 1999; Rhodes and Gil 2002).

\section{The operational context}

The research was conducted at a medium-sized UK-registered airline that operated Airbus single-aisle aircraft (A320s and A321s) over short- and medium-haul routes. The airline had implemented EASA's new flight and duty-time regulations a few months before the research commenced. Although financial difficulties in 2014 and a subsequent change of ownership may have affected morale, no Captain refused the author access. Bennett (2003) notes that pilots welcome opportunities to unburden. Two short, potentially high-workload routes were surveyed. Normally, crews operating the routes flew no more than two sectors per day. ${ }^{3}$ At BHX, a seven -day run of duties was possible. ${ }^{4}$ Pilots operating the two routes could be rostered multiple consecutive early starts. One pilot, rostered on the early BHX-PMI-BHX for a fifth consecutive day, noted on his WorkFat form: 'Fifth very early report in a row. Woke up on alarm at 03:30z. [Yesterday's] Madeira had been challenging. Felt OK, so 
decided to operate the flight. Cumulative fatigue kicking in as flight progressed'. His final WorkFat comment was: 'Nothing missed, but had to confirm calls and checks, as could not remember if done' (see PN13, below). ${ }^{5}$ His subjective fatigue ratings were as follows:

\begin{tabular}{lcccc}
\hline \multicolumn{5}{c}{ BHX-PMI-BHX } \\
\hline & \multicolumn{4}{c}{ Subject fatigue (SF) } \\
\cline { 2 - 5 } Element & Outbound & Time noted & Inbound & Time noted \\
\hline Boarding - Off blocks (B-O) & 4 & $06: 00$ & 5 & $10: 30$ \\
Off blocks - Top of climb (O-T) & 4 & $06: 50$ & 5 & $10: 30$ \\
Top of climb - Top of descent (T-T) & 4 & $07: 30$ & 6 & $11: 30$ \\
Top of descent - On blocks (T-O) & 5 & $08: 10$ & 6 & $12: 25$ \\
& All times Zulu & & & \\
5= Moderately tired: let down & & & & \\
6= Extremely tired: very difficult to concentrate & & & \\
\hline
\end{tabular}

The scheduled flight times for the two routes during the research period were:

\begin{tabular}{ll}
\hline & Scheduled flight times \\
\hline BHX-NCE & $130 \mathrm{~min}$ \\
BHX-PMI & $145 \mathrm{~min}$ \\
\hline
\end{tabular}

The author's jump-seat observations confirmed that actual flight times were usually less than scheduled flight times, and that turnarounds were usually accomplished in less than an hour. (At the subject airline, contractors cleaned the aircraft at turnaround. Other carriers flying the same routes required cabin and flight crew to clean the aircraft). On the flights where accurate turnaround timings were taken, it took an average of 59 min to turn an aircraft around. The ethnographic data showed that aircraft arrived back at BHX more or less on schedule.

The WorkFat form allowed pilots to note the day they performed the flight out of a run of days. For example, if the flight was performed on day two out of a four -day run, it would be recorded as $2 / 4$. The following table summarises the data:

\begin{tabular}{|c|c|c|c|c|c|c|c|c|}
\hline \multirow[b]{2}{*}{ Run (days) } & \multicolumn{8}{|c|}{ Day number } \\
\hline & 1 & 2 & 3 & 4 & 5 & 6 & 7 & Total \\
\hline 1 & 2 & & & & & & & 2 \\
\hline 2 & 3 & 5 & & & & & & 8 \\
\hline 3 & 3 & 6 & 8 & & & & & 17 \\
\hline 4 & 4 & 5 & 11 & 8 & & & & 28 \\
\hline 5 & 5 & 7 & 7 & 6 & 8 & & & 33 \\
\hline 6 & 0 & 2 & 2 & 1 & 2 & 5 & & 12 \\
\hline 7 & & & & & & & 1 & 1 \\
\hline Total & 17 & 25 & 28 & 15 & 10 & 5 & 1 & \\
\hline
\end{tabular}


Day number data was recorded on 101 of the 110 forms submitted. The largest number of forms were completed by pilots on day three of a four-day run (11 forms). Five-day runs were most prevalent. Twelve forms were completed by pilots who had been rostered a six-day run. One pilot (a management pilot, specifically the Base Captain) was on day seven of a seven-day run. He wrote: 'Day seven of seven. Earlies onto lates' (N4). His subjective fatigue ratings for his day 7 NCE were:

\begin{tabular}{lcccc}
\hline \multicolumn{5}{c}{ BHX-NCE-BHX } \\
& \multicolumn{4}{c}{ SF } \\
\cline { 2 - 5 } Element & Outbound & Time noted & Inbound & Time noted \\
\hline B-O & 2 & $15: 05$ & 3 & $17: 50$ \\
O-T & 3 & $15: 05$ & 4 & $?$ \\
T-T & 3 & $17: 47$ & 2 & $18: 20$ \\
T-O & \multicolumn{1}{c}{ Key } & & \\
& Boarding - Off blocks & & \\
B-O & Off blocks - Top of climb & & \\
O-T & Top of climb - Top of descent & \\
T-T & Top of descent - On blocks & & \\
T-O & &
\end{tabular}

\section{Research method and instruments}

An inductive approach was used. With reference to Bogdan and Taylor's (1975), Berger and Mohr's (2010), ${ }^{6}$ Gilbert's (1993), Harvey and MacDonald's (1993) and Burns's (2000) discourses on ethnography, oral history and subjectivity, by mixing data generated by instantaneous self-assessment (ISA) (the WorkFat form recorded workload, fatigue and narrative data) with data gleaned from third-party observations (the author's jump-seat rides that allowed him to observe the operation and talk with flight crew), the research generated quantitative and qualitative insights into the flight-deck labour process. Pickup et al. (2005) claim that observations made by human factors specialists provide useful insights.

Regarding the choice of research instrument (WorkFat), while other human factors ISA research instruments are available, for example, NASA's Task Load Index (TLX), the Subjective Workload Assessment Technique (SWAT), and the Workload Profile (WP) (Hart and Staveland 1988; Rubio et al. 2004), none of these instruments ${ }^{7}$ allow subjects to estimate their fatigue directly. For example, the TLX uses 21-point scales to measure: 'Mental Demand (How mentally demanding was the task?); Physical Demand (How physically demanding was the task?); Temporal Demand (How hurried or rushed was the pace of the task?); Performance (How successful were you in accomplishing what you were asked to do?); Effort (How hard did you have to work to accomplish your level of performance?); Frustration (How insecure, discouraged, irritated, stressed, and annoyed were you?)' (National Aeronautics and Space Administration 2016). Further, unlike the WorkFat form, the standard TLX form (see National Aeronautics and 
Space Administration 2016) does not provide space for comments. In mixedmethods studies such as this, subjects' comments provide useful contextual data. In this project, they supplemented the participant observation data.

The WorkFat form recorded pilots' self-assessed:

- Maximum workload (a circled number)

- Average workload (a crossed number)

- Fatigue (a circled number)

The form provided space for comments, pilots being encouraged to make observations with this exhortation: 'Please make a note of diverts. Roster information is also useful.'

WorkFat's seven-point workload and fatigue scales carried the following descriptors:

Workload scale

\begin{tabular}{ll}
\hline 1 & Nothing to do: no system demands \\
2 & Little to do: minimum system demands \\
4 & Active involvement required: but easy to keep up \\
5 & Challenging: but manageable \\
6 & Extremely busy: barely able to keep up \\
7 & Too much to do: overloaded and postponing some \\
& tasks \\
& Unmanageable: potentially dangerous and \\
\hline
\end{tabular}

Fatigue scale

\begin{tabular}{ll}
\hline 1 & Fully alert and wide awake: extremely peppy \\
2 & Very lively: responsive, but not at peak \\
3 & Okay: somewhat fresh \\
4 & A little tired: less than fresh \\
5 & Moderately tired: let down \\
6 & Extremely tired: very difficult to concentrate \\
7 & Completely exhausted: unable to function \\
& effectively \\
\hline
\end{tabular}

As per the colour codings, responses were grouped to facilitate analysis. A traffic-light pattern (green, amber, red) was used: Green = low risk; Amber = medium risk; Red = high risk. The diary kept by the observer is shown at Figure 1. 


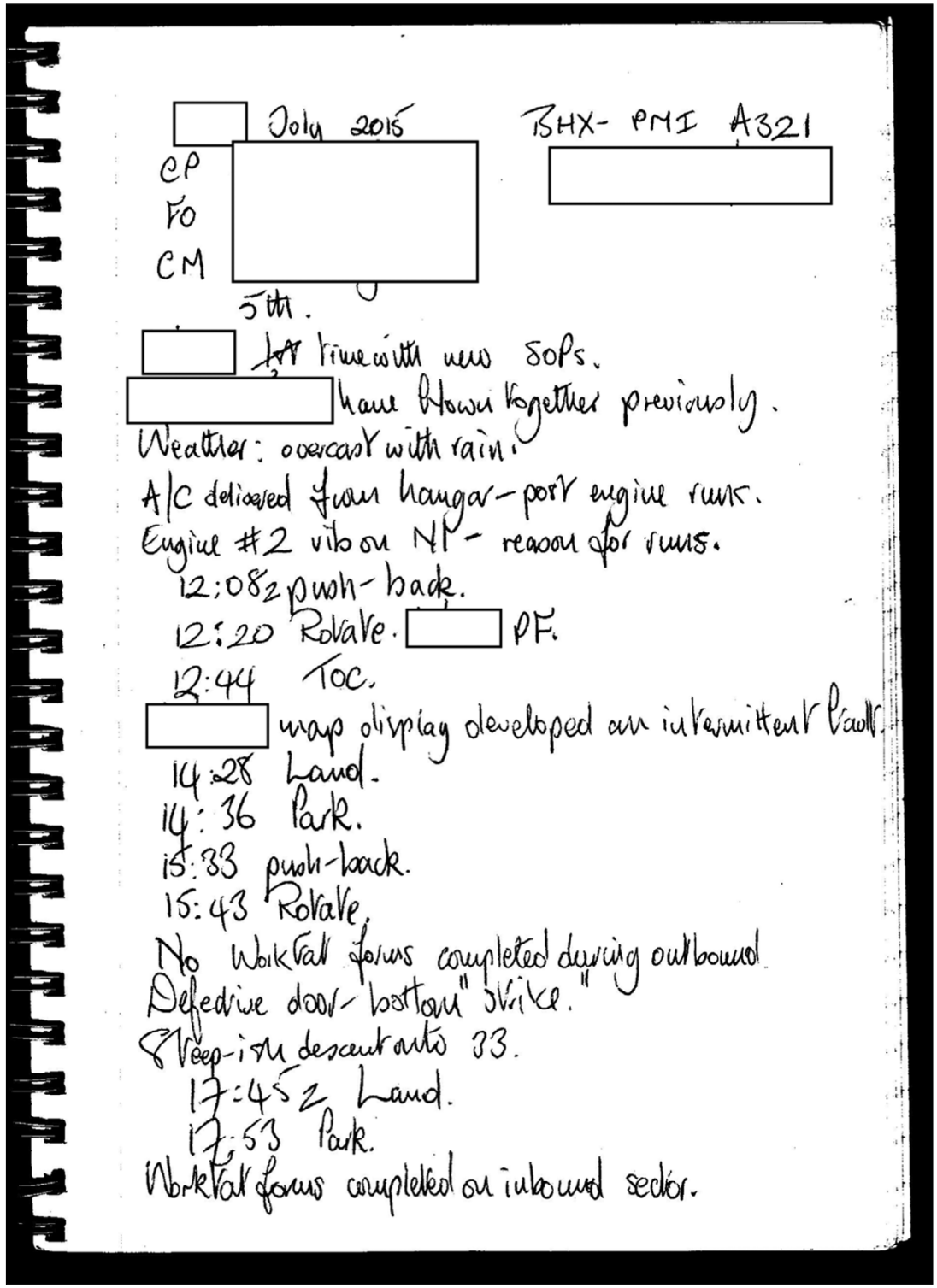

Figure 1. The author's diarisation of a BHX-PMI-BHX service (flight and cabin crew names and other identifiers have been redacted).

In summary, the quantitative and qualitative (ethnographic) data created a high-fidelity account of the flight-deck labour process at a single airline on two intra-European routes during the summer/autumn season (generally a busy time for an airline). There are relatively few ethnographic accounts of commercial aviation operations. Bennett's (2003, 2006a,b, 2010, 2014), Ginnett's (1990), Haertner's (2011) and Helmreich and Merritt's (1998) accounts are the exception. 


\section{A reflexive commentary on the research method}

Reflective practice (Dewey 1933; Schön 1983; Bolton 2010) encourages transparency:

- The research builds on earlier work, a common approach in the social sciences (Gilbert 1993).

- There is disagreement as to whether ISA accurately measures fatigue and stress (Pickup et al. 2005; Baron 2009; Caldwell et al. 2009; Eurocontrol 2012).

- Because meaning is actively constructed (Bartlett 1932; Bruner 1986; Vygotsky and Kozulin 1986), ${ }^{8}$ it is possible that the meanings ascribed by pilots to the WorkFat form's descriptors of loading and physical states differed.

- Funding and time constraints, plus the author's desire not to overstress a pilot community that had faced the possibility of redundancy ${ }^{9}$ meant that two routes were surveyed.

- The number of WorkFat forms returned was less than the number of services to NCE and PMI during the two research periods. A total of 132 company services were flown to NCE and PMI. One hundred and ten forms were returned, ${ }^{10}$ a completion rate of $83 \%{ }^{11}$ The author's presence on the flightdeck did not guarantee that WorkFat forms would be completed.

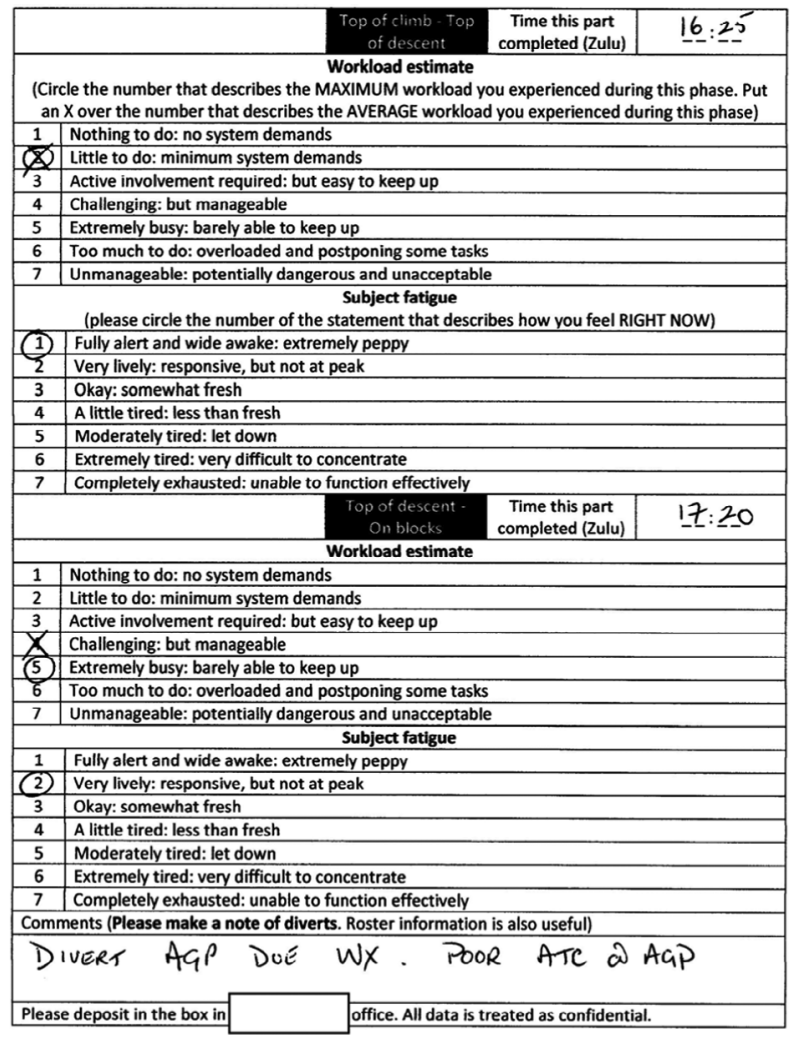

Figure 2. The model WorkFat form showing how it should be completed. 
- Despite efforts to show pilots how the forms should be completed (for example, by asking that the 'model WorkFat form' (see Figure 2) be circulated), only 34 forms were completed 100\% correctly. ${ }^{12}$ Problems included (and see Figures 3 and 4):

- No data entered for elements of the flight (e.g. Boarding to Off Blocks).

- A form being completed for just one leg (just the outbound leg, or just the inbound leg).

- The Average Workload symbol (a crossed number) being confused with the Maximum Workload symbol (a circled number), despite a key being printed on every form.

- Circling a single number on the Workload scale. Did the pilot intend this to signify maximum, or average workload?

- Circling two numbers. In cases where it was unclear which number the pilot intended as her/his answer, the lower value was recorded (giving the data a conservative bias).

- Despite encouraging pilots to use the Comments boxes to provide contextual information (for example, the duration and quality of pre-report sleep), few did so.

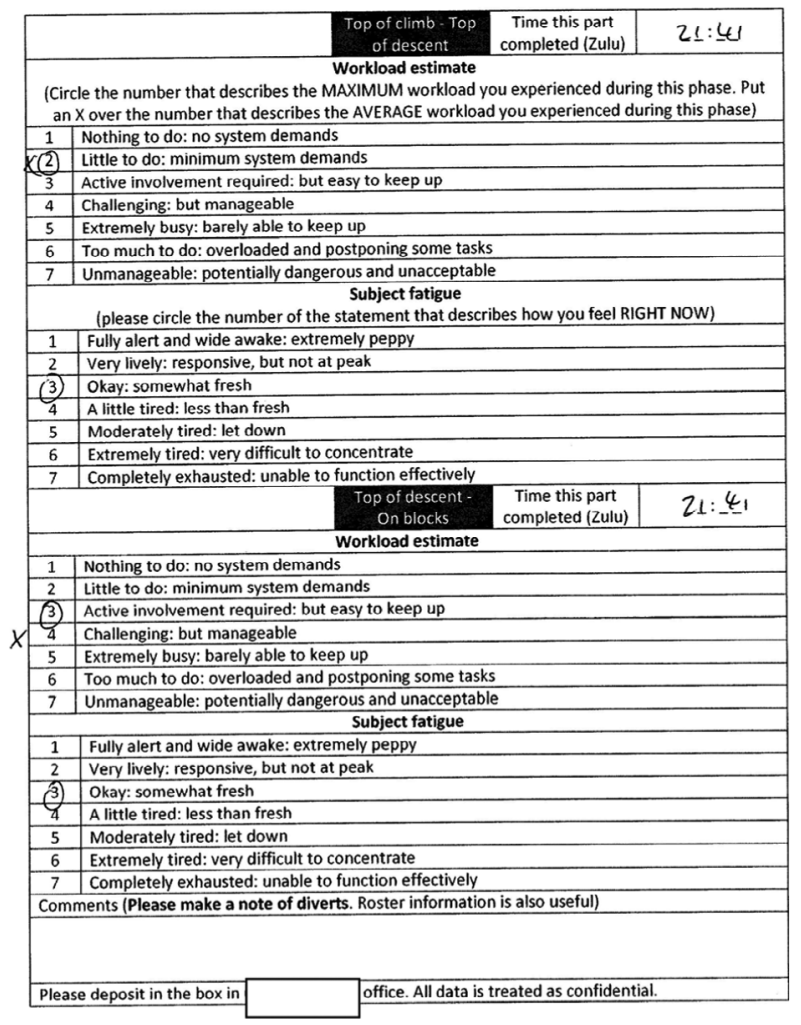

Figure 3. Actual return: confusing the maximum workload and average workload symbols. 


\begin{tabular}{|c|c|c|c|}
\hline & $\begin{array}{l}\text { Top of climb-Top } \\
\text { of descent }\end{array}$ & $\begin{array}{l}\text { Time this part } \\
\text { completed (Zulu) }\end{array}$ & L2: 15 \\
\hline \multicolumn{4}{|c|}{$\begin{array}{l}\text { Workload estimate } \\
\text { (Circle the number that describes the MAXIMUM workload you experienced during this phase. Put } \\
\text { an } \mathrm{X} \text { over the number that describes the AVERAGE workload you experienced during this phase) }\end{array}$} \\
\hline 1 & \multicolumn{3}{|c|}{ Nothing to do: no system demands } \\
\hline (2) & \multicolumn{3}{|l|}{ Little to do: minimum system demands } \\
\hline 3 & \multicolumn{3}{|l|}{ Active involvement required: but easy to keep up } \\
\hline 4 & \multicolumn{3}{|l|}{ Challenging: but manageable } \\
\hline 5 & \multicolumn{3}{|l|}{ Extremely busy: barely able to keep up } \\
\hline 6 & \multicolumn{3}{|l|}{ Too much to do: overloaded and postponing some tasks } \\
\hline 7 & \multicolumn{3}{|l|}{ Unmanageable: potentially dangerous and unacceptable } \\
\hline \multicolumn{4}{|c|}{$\begin{array}{l}\text { Subject fatigue } \\
\text { (please circle the number of the statement that describes how you feel RIGHT NOW) }\end{array}$} \\
\hline 1 & \multicolumn{3}{|c|}{ Fully alert and wide awake: extremely peppy } \\
\hline 2 & \multicolumn{3}{|l|}{ Very lively: responsive, but not at peak } \\
\hline (3) & \multicolumn{3}{|l|}{ Okay: somewhat fresh } \\
\hline 4 & \multicolumn{3}{|l|}{ A little tired: less than fresh } \\
\hline 5 & \multicolumn{3}{|l|}{ Moderately tired: let down } \\
\hline 6 & \multicolumn{3}{|l|}{ Extremely tired: very difficult to concentrate } \\
\hline 7 & \multicolumn{3}{|l|}{ Completely exhausted: unable to function effectively } \\
\hline & \begin{tabular}{|c|c|}
$\begin{array}{c}\text { Top of descent - } \\
\text { On blocks }\end{array}$ \\
\end{tabular} & $\begin{array}{l}\text { Time this part } \\
\text { completed (Zulu) }\end{array}$ & $12: 38$ \\
\hline \multicolumn{4}{|c|}{ Workload estimate } \\
\hline 1 & \multicolumn{3}{|l|}{ Nothing to do: no system demands } \\
\hline 2 & \multicolumn{3}{|l|}{ Little to do: minimum system demands } \\
\hline (3) & \multicolumn{3}{|l|}{ Active involvement required: but easy to keep up } \\
\hline 4 & \multicolumn{3}{|l|}{ Challenging: but manageable } \\
\hline 5 & \multicolumn{3}{|l|}{ Extremely busy: barely able to keep up } \\
\hline 6 & \multicolumn{3}{|l|}{ Too much to do: overloaded and postponing some tasks } \\
\hline 7 & \multicolumn{3}{|l|}{ Unmanageable: potentially dangerous and unacceptable } \\
\hline \multicolumn{4}{|c|}{ Subject fatigue } \\
\hline 1 & \multicolumn{3}{|l|}{ Fully alert and wide awake: extremely peppy } \\
\hline 2 & \multicolumn{3}{|l|}{ Very lively: responsive, but not at peak } \\
\hline 3 & \multicolumn{3}{|l|}{ Okay: somewhat fresh } \\
\hline (4) & \multicolumn{3}{|l|}{ A little tired: less than fresh } \\
\hline 5 & Moderately tired: let down & & \\
\hline 6 & Extremely tired: very difficult to concentrate & & \\
\hline 7 & Completely exhausted: unable to function effectively & & \\
\hline Comn & nents (Please make a note of diverts. Roster information & is also useful) & \\
\hline Please & deposit in the box in & eated as confidenti & \\
\hline
\end{tabular}

Figure 4. Actual return: Incomplete workload score. Did the pilot intend the circled number to represent maximum or average workload?

\section{Data}

\section{Introduction}

The WorkFat data comprised:

$\mathrm{BHX}-\mathrm{NCE}-\mathrm{BHX} 23$ forms (partially and fully completed).

BHX-PMI-BHX 87 forms (partially and fully completed).

Because fatigue and workload were recorded by flight-phase (outbound and inbound (see Figure 2)), it was decided to include partially completed forms. The inclusion of this data means that the base number for returns by flight-phase varies. The author's flight-deck observations ${ }^{13}$ (reproduced in the Appendix 1) and pilots' narratives $^{14}$ (reproduced verbatim in the Appendix 1) constitute the ethnographic element of the research. 
Crew status survey

Workload 1-2 and Fatigue 1-3

\begin{tabular}{|c|c|c|c|c|c|c|}
\hline \multirow[b]{2}{*}{ Table 1. Flight phase } & \multicolumn{2}{|c|}{$\begin{array}{l}\text { Maximum workload, } \\
\text { in range } 1-2 \text { as } \\
\text { percentage }\end{array}$} & \multicolumn{2}{|c|}{$\begin{array}{l}\text { Average workload, in } \\
\text { range } 1-2 \text { as } \\
\text { percentage }\end{array}$} & \multicolumn{2}{|c|}{$\begin{array}{c}\text { Fatigue, in range } 1-3 \\
\text { as percentage }\end{array}$} \\
\hline & Outbound & Inbound & Outbound & Inbound & Outbound & Inbound \\
\hline $\mathrm{B}-\mathrm{O}$ & $5.0(3)^{15}$ & $8.8(5)$ & $33.3(20)$ & $36.8(21)$ & $51.5(50)$ & $39.2(38)$ \\
\hline $\mathrm{O}-\mathrm{T}$ & $19.6(10)$ & $13.5(7)$ & $39.2(20)$ & $34.0(18)$ & $54.6(53)$ & $35.4(34)$ \\
\hline $\mathrm{T}-\mathrm{T}$ & $22.8(13)$ & $25.0(14)$ & $48.2(27)$ & $54.4(31)$ & $49.4(48)$ & $26.8(26)$ \\
\hline $\mathrm{T}-\mathrm{O}$ & $5.9(3)$ & $3.8(2)$ & $17.6(9)$ & $13.2(7)$ & $50.5(48)$ & $23.2(22)$ \\
\hline \multicolumn{7}{|c|}{ Key } \\
\hline $\mathrm{B}-\mathrm{O}$ & \multicolumn{6}{|c|}{ Boarding - Off blocks } \\
\hline $\mathrm{O}-\mathrm{T}$ & \multicolumn{6}{|c|}{ Off blocks - Top of climb } \\
\hline $\mathrm{T}-\mathrm{T}$ & \multicolumn{6}{|c|}{ Top of climb - Top of descent } \\
\hline $\mathrm{T}-\mathrm{O}$ & \multicolumn{6}{|c|}{ Top of descent - On blocks } \\
\hline
\end{tabular}

Workload 3-4 and Fatigue 4-5

\begin{tabular}{|c|c|c|c|c|c|c|}
\hline \multirow[b]{2}{*}{ Table 2. Flight phase } & \multicolumn{2}{|c|}{$\begin{array}{l}\text { Maximum workload, } \\
\text { in range } 3-4 \text { as } \\
\text { percentage }\end{array}$} & \multicolumn{2}{|c|}{$\begin{array}{l}\text { Average workload, in } \\
\text { range } 3-4 \text { as } \\
\text { percentage }\end{array}$} & \multicolumn{2}{|c|}{$\begin{array}{c}\text { Fatigue, in range } 4-5 \\
\text { as percentage }\end{array}$} \\
\hline & Outbound & Inbound & Outbound & Inbound & Outbound & Inbound \\
\hline B-O & $93.3(56)$ & $87.7(50$ & $66.7(40)$ & $63.1(36)$ & $45.4(4$ & $55.7(54)$ \\
\hline $\mathrm{O}-\mathrm{T}$ & $80.4(41)$ & $84.6(44)$ & $60.8(31)$ & $66.1(35)$ & $43.3(42)$ & $60.5(58)$ \\
\hline $\mathrm{T}-\mathrm{T}$ & $77.2(44)$ & $75.0(42)$ & $51.8(29)$ & $45.7(26)$ & $48.4(47)$ & 60.9 (59) \\
\hline $\mathrm{T}-\mathrm{O}$ & $94.1(48)$ & 90.3 (47) & $82.3(42)$ & $84.9(45)$ & $47.4(45)$ & $63.1(60)$ \\
\hline
\end{tabular}

Workload 5-7 and Fatigue 6-7

\begin{tabular}{|c|c|c|c|c|c|c|}
\hline \multirow[b]{2}{*}{ Table 3. Flight phase } & \multicolumn{2}{|c|}{$\begin{array}{l}\text { Maximum workload, } \\
\text { in range } 5-7 \text { as } \\
\text { percentage }\end{array}$} & \multicolumn{2}{|c|}{$\begin{array}{l}\text { Average workload, } \\
\text { in range } 5-7 \text { as } \\
\text { percentage }\end{array}$} & \multicolumn{2}{|c|}{$\begin{array}{c}\text { Fatigue, in range 6-7 } \\
\text { as percentage }\end{array}$} \\
\hline & Outbound & Inbound & Outbound & Inbound & Outbound & Inbound \\
\hline B-O & $1.7(1)$ & $3.5(2)$ & $0(0)$ & $0(0)$ & $3.1(3)$ & $5.2(5)$ \\
\hline $\mathrm{O}-\mathrm{T}$ & $0(0)$ & $1.9(1)$ & $0(0)$ & $0(0)$ & $2.1(2)$ & $4.1(4)$ \\
\hline $\mathrm{T}-\mathrm{T}$ & $0(0)$ & $0(0)$ & $0(0)$ & $0(0)$ & $2.1(2)$ & $12.4(12)$ \\
\hline $\mathrm{T}-\mathrm{O}$ & $0(0)$ & $5.8(3)$ & $0(0)$ & 1.9 (1) & $2.1(2)$ & $13.7(13)$ \\
\hline
\end{tabular}

\section{Analysis}

The data shows that pilots rarely assessed workload and fatigue to be 'high-risk' (defined here as scores 5-7 for workload, and scores 6-7 for fatigue). Having said this, two returns stand out: $12.4 \%$ of those who completed the inbound Top-ofClimb - Top-of-Descent scale claimed to be either 'Extremely tired' or 'Completely exhausted'; $13.7 \%$ of those who completed the inbound Top-of-Descent - OnBlocks scale claimed to be either 'Extremely tired' or 'Completely exhausted'. 
The ethnographic data illustrates the practical consequences of sleep loss and (perceived) fatigue. After operating two High Season (June) earlies out of Gatwick, a pilot on day three of five noted of his BHX-PMI-BHX: 'Yesterday was very tiring. Roster is LGW for two earlies. Early Dalaman, then LGW-PMI. Back to BHX straight afterwards, to do three more earlies. Waking up between 03:00 and 04:00 to report on-time for each. I was rostered BHX-DLM today (day three of five) but spoke to crewing to move to a shorter flight ... Still unsure whether I will be able to manage all five earlies. Generally getting six hours sleep each night, so after five I am in ten hours sleep debt. Always feel a low on return sector of an early start. I struggle to keep my eyes open. I made a lot of stupid mistakes yesterday, saying the wrong words, or just doing the wrong thing'. ${ }^{16}$ His self-assessed fatigue level on the outbound leg (BHX-PMI) was consistently 4, and on the inbound leg consistently 5 .

A pilot on day six of six noted of his BHX-PMI-BHX early departure: 'More tired than usual. Am having to double-check actions. Day six, of six earlies. Very early departures [woke at 01:55z for scheduled 05:10z departure]'. His self-assessed fatigue level on the return leg was consistently 5. The mind and body are at their least efficient during the circadian low (approximately 03:00-06:00) (Rhodes and Gil 2002). Sleep debt has cognitive impacts:

Lack of sleep ... will quickly result in mental fatigue. You become increasingly inattentive while trying to concentrate on your tasks. As fatigue increases, your short-term memory becomes less effective and you may forget vital information. Your creativity and decision-making abilities start to wane and you have more difficulty dealing with novel situations. (Rhodes and Gil 2002, 20)

By way of comparison, a management pilot on day seven of seven operating BHX-NCE during High Season (July) assessed his fatigue at 2-3 for most elements and 4 for Off-blocks - Top-of-climb. Sleep requirements and stress tolerances vary (Green et al. 1996; Campbell and Bagshaw 1999; Dekker 2007; Caldwell et al. 2009). Dekker (2007, 6) notes of subjects' reactions to stress: 'Not everybody experiences the same situation in the same way. It depends on experience, proficiency, time of day, familiarity, disposition and so on.' Caldwell et al. $(2009,52)$ note of subjects' reactions to fatigue: '[T] here are wide individual differences in fatigue susceptibility'.

The data shows that pilots consistently assessed fatigue types 4 and 5 (a little tired/moderately tired) to be more prevalent on the inbound sector. The ethnographic study showed that aircraft approaching BHX can be kept high by ATC, necessitating a rapid, high-workload descent. Scores of 5-7 for Maximum Workload, 5-7 for Average Workload and 3-4 for Average Workload were seen most often for the descent into BHX. These findings resonate with Lee's $(2010$, ii) TLX-informed research into pilot workload and stress: 'Five students and five instructor pilots from EmbryRiddle Aeronautical University ... participated ... [T] hey flew under four different simulation tasks of gliding angle and approach area. Their Heart Rate Variability and TLX were measured to determine their stress level and subjective workload, respectively'. Lee's data revealed a positive correlation between flying operations over populated areas and pilot workload and stress. It also revealed a positive correlation between angle of descent and pilot workload and stress. Lee gathered human factors data from two descent profiles: a 3.0 degree approach and a 4.5 degree 
approach: 'During the flight with 4.5 degree [sic], the pilots showed lower performance with higher workload and stress' (Lee 2010, iii).

The data shows that pilots associated maximum workload with flight-phases Boarding - Off-blocks and Top-of-descent - On-blocks. The ethnographic study showed how programming the flight-management computer, reviewing the Technical Log, fuelling, general form-filling (completing manual load sheets and signing-off the fuel uplift, for example), technical faults like defective auxiliary power units (see PN14), no-show passengers and the need to offload bags increased pilots' workload prior to push-back. Flight-deck visits (for example, by the Fueller, Dispatcher or Cabin Manager) interrupted the flow of work. It was usual for pilots to immediately attend to visitors. Viewed through a Line Operations Safety Audit (LOSA) (International Civil Aviation Organisation 2002; Federal Aviation Administration 2006) prism, interruptions to flight-deck routines are potential threats to safety. ${ }^{17}$

The ethnographic data revealed how circumstance could impact workload, as with the First Officer left to set the aircraft up on his own because his Captain was delayed by traffic. The Captain arrived on the flight-deck ten minutes before push-back. It was not until the aircraft was in the climb that the Captain became fully situation-aware (see N5). Viewed through a LOSA prism, poor situationawareness is a potential threat to safety.

The data shows that pilots assessed fatigue types 4 and 5 (a little tired/moderately tired) to be more prevalent as the duty unfolded. This suggests a positive relationship between elapsed flight duty time and fatigue types 4 and 5. Powell et al. (2007) note a linear relationship between duty length and fatigue. Pilots scored the cruise portion of the flight (Top-of-Climb - Top-of-Descent) as having the lightest workload, with the inbound cruise portion of the flight having the lowest workload. The ethnographic study showed that pilots completed a variety of duty paperwork on the outbound sector. This may explain why some pilots delayed completing their WorkFat form until the aircraft was in the cruise on the return leg (see, for example, P3). One pilot commented: 'Too busy to fill this form in on the outbound sector, so I filled it in retrospectively' (NN4).

The $83 \%$ completion rate and $69 \%$ error rate ${ }^{18}$ suggest that claims made for the CSS - for example, that it is 'easily understood' and 'easy to complete in the field' - merit scrutiny. Viewed through a systems-thinking (Perrow 1983; Reason 2013; Dekker 2014; Waterson and Catchpole 2015) lens, take-up and quality may have been influenced by:

- morale

- preoccupations (for example, job security, changes in terms and conditions)

- perceptions of management-sanctioned academic research

- inertia induced by an embedded flight-deck modus operandi

- a desire to meet on-time performance (OTP) targets that meant WorkFat was given a relatively low priority (see PN8)

- the lived reality of a work environment where safety is paramount and the mantra 'aviate, navigate, communicate' orders flight-deck activity (Morris and Leung 2006).

Findings suggest that claims made for other human factors ISA instruments merit scrutiny. Rubio et al. (2004) evaluated three human factors ISA instruments: TLX, the SWAT and the WP against six criteria: intrusiveness; sensitivity; convergent 
validity; concurrent validity; diagnosticity; and implementation requirements and acceptability. The success with which each instrument satisfied the six criteria varied. For example, in regard to the success with which the final criteria (implementation requirements and acceptability) was satisfied, the authors comment: 'Subjects accepted willingly the three instruments, although there were some problems concerning comprehension of the dimensions in the WP. As for the SWAT, the ranking task prior to the performance of the experimental tasks proved wearisome' (Rubio et al. 2004, 83). The authors conclude with an appeal for further refinement of TLX, the SWAT and the WP, and development of new research instruments:

[W]e want to emphasise the need for continued research in subjective mental workload that serves to develop better human information processing models, to design new measure procedures, and to improve the properties of the existing assessment instruments. (Rubio et al. 2004, 83)

To summarise: while the CSS research instrument may harbour weaknesses and lacunae, so might the TLX, SWAT and WP research instruments (and, one suspects, other human factors data-gathering instruments, too).

The ethnographic study showed flight phases Boarding - Off- blocks and Offblocks -Top of climb to be generally busy and demanding, with the latter phase especially so. Actions during critical phases of flight like Off-blocks -Top-of-climb are dictated by the nature of the activity (taxiing an aircraft through a busy and complex ground environment, then taking it safely into the air). Both the pilot flying $(\mathrm{PF})$ and pilot monitoring $(\mathrm{PM})$ are required to respond to routine demands (steering the aircraft and actioning ATC instructions, for example), solve expected and unexpected problems (threats) ${ }^{19}$ and trap and correct errors. Flight deck activities are further shaped by processes of routinisation, standardisation and prescription. 'Much of the human work on a flight deck is prescribed' note Wright, Pocock, and Fields $(1998,1)$. The $83 \%$ return rate and $69 \%$ error rate suggest it can be difficult to introduce additional routines into a demanding environment - even minimally intrusive routines like completing Likert scales for workload and fatigue. Initiatives may be frustrated by praxis (Schermerhorn, Hunt, and Osborn 2005). Further, the organisational context was not conducive to additional demands. The ethnographic study revealed cynicism and low morale amongst some pilots. ${ }^{20}$ It is reasonable to assume that this background affected the response. Initiatives may be frustrated by circumstance (Schermerhorn, Hunt, and Osborn 2005).

\section{Conclusions}

The data suggests that, contrary to expectations, EASA's flight and duty -time regulations are not inducing dangerous levels of fatigue (as self-assessed by pilots). Having said this, the results should be treated with caution. Reasons include:

- Only two routes from a single base were surveyed. Consequently, the data may be unrepresentative.

- The operation is not representative of the industry as a whole. Pilots do not routinely operate four sector days. ${ }^{21}$ Powell et al. $(2007,701)$ state: 'The most important influences on fatigue [are] the number of sectors [flown] and duty length'. Also, at turnaround, contractors rather than crewmembers cleaned the cabin. 
- The surveyed routes were short. The inclusion of longer company routes, like Birmingham to Sharm El Sheik (BHX-SSH-BHX), may produce different results. According to Powell et al. (2007), there is a linear relationship between duty length and fatigue.

- Pilots' duty not to fly when fatigued may have skewed the results. Despite assurances of confidentiality, it is possible that some respondents under-stated their fatigue for fear of incriminating themselves.

- There is disagreement as to whether self-assessment accurately measures capacity. Powell et al. (2007, 701) state: '[Samn-Perelli] scores have been shown to follow similar trends to objective measures'. Campbell and Bagshaw (1999, 140) assert: 'Individuals tend to report a greater level of alertness than is actually the case'. Caldwell et al. $(2009,52)$ assert: 'People cannot reliably self-judge their own level of fatigue-related impairment'.

- The ethnographic data (especially pilots' narratives) suggests that some pilots may have experienced acute or chronic fatigue, although one should be mindful of Caldwell et al.'s (2009) claim (above) when drawing on narrative accounts.

- Most observed crews had flown together previously. Non-familiarity with a flight-deck colleague is a potential threat to safety.

The data suggests that on the two routes surveyed, workload was generally not considered excessive. The ethnographic study showed how factors beyond the control of the pilots (for example, slots, ${ }^{22}$ missing passengers, technical faults, flight-deck interruptions, inadequate ground-handling resources, procedures and skills ${ }^{23}$ and airspace manoeuvring restrictions) conspired to increase workload. Seen through the LOSA prism, such events are potential threats to safety and efficiency. Finally, the data suggests that claims made for the functionality and workplace acceptability of the CSS are open to question. Having said this, the research was conducted under less-than-ideal circumstances. Buy-in can be improved by tailoring methodology to circumstance. The systems-thinking prism can help reveal obstacles to research.

\section{Disclosure statement}

No potential conflict of interest was reported by the author.

\section{Notes}

1. Developing a sociology of the flight-deck has seen the author spend $1386 \mathrm{~h}$ on the jump-seat, accumulated as follows: 232 sectors on the A319; 50 sectors on the A320; 42 sectors on the $\mathrm{A} 321 ; 82$ sectors on the $\mathrm{B} 737 ; 181$ sectors on the $\mathrm{B} 757 ; 7$ sectors on the A300. A sector is a point-to-point flight. The author has flown gliders and has performed a landing in a 737-300 simulator. He has SEP'd on several types.

2. The ethnographic data is reproduced in the Appendix 1. Flight-deck observations are coded: N1-N9 and P1-P3. Pilots' narratives are coded: NN1-NN4 and PN1-PN24.

3. The ethnographic study revealed that pilots on a short duty might occasionally be required to operate one or two positioning flights post-duty (see $\mathrm{N} 9$ and $\mathrm{NN} 3$, below).

4. One large UK-registered low-cost carrier limits the number of consecutive days a pilot can fly to five. A five on, four off, five on, three off pattern obtains. Five consecutive early starts are a possibility. The pattern is Civil Aviation Authority approved.

5. Research conducted with pilots at a low-cost carrier in 2001 (Bennett 2003) produced similar claims. 
6. Berger and Mohr (2010, 96-98) observe: 'To try to understand the experience of another it is necessary to dismantle the world as seen from one's own place within it, and to re-assemble it as seen from his ... [T] he subjectivity of another does not simply constitute a different interior attitude to the same exterior facts. The constellation of facts of which he is the centre is different'. Through lawyer Atticus Finch, Lee (1960, 30) observes: 'You never really understand a person until you consider things from his point of view ... until you climb into his skin, and walk around in it.'

7. Rubio et al. $(2004,61)$ found that ' $\ldots$ the diagnostic power of WP was clearly superior to that obtained using TLX or SWAT.'

8. Bartlett describes the active construction of meaning as 'conventionalisation'.

9. Jeopardy may induce emotional reactions (Briner and Totterdell 2002).

10. Two sets of WorkFat forms were automatically printed with the flight documents.

11. Forms where data for only one leg was entered are included in this figure.

12. The errors were usually singular and minor.

13. Coded: N1-N9 and P1-P3.

14. Coded: NN1-NN4 and PN1-PN24.

15. Number of times pilots chose this data field.

16. In 2001, pilots operating under the CAP371 flight and duty -time regulations made similar claims (Bennett 2003). These pilots, however, worked for a low-cost carrier where four-sector days were the norm (for example, STN-EDI-STN-EDI-STN). Occasionally, five-sector days were flown.

17. The purpose of a LOSA is to identify threats and errors in support of proactive riskmanagement. It is analogous with preventive medicine in health care (Federal Aviation Administration 2006).

18. The errors were usually singular and minor.

19. Threats include slot restrictions (see, for example, PN17 and PN18), adverse weather and traffic conflicts.

20. Resulting from the airline's 2014 financial problems, the possibility of corporate failure, introduction of less attractive terms and conditions as one element of the rescue package and diminution of final salary pension for some long-serving pilots.

21. Pilots on a short duty might occasionally be required to operate one or two positioning flights.

22. A slot, or calculated take-off time, requires the PF to have the aircraft ready for take-off at the designated slot time.

23. For example, no steps to the rear door, only one bus to the aircraft, defective ground equipment (a fuel bowser broke down) and ground handlers unable to correctly position aircraft steps.

24. NCE has two parallel runways, $04 \mathrm{~L}$ and $04 \mathrm{R}$. At NCE a visual approach may be flown. Amongst other things, a visual approach involves disconnecting the Autopilot and clearing the Flight Director command bars. The objective is to land using visual references only (Flight Safety Foundation 2000).

25. The FO ceded control without being ordered to. Green et al. $(1996,105)$ note: ' $[\mathrm{I}] \mathrm{t}$ can be very difficult for one pilot to take control away from the other'. This was exemplary teamwork in the best traditions of crew resource management (CRM) (McAllister 1997).

26. To avoid duplication of data, WorkFat forms completed during observed flights (see above) that contained pilot narrative accounts are not reproduced here.

\section{References}

Baron, R. 2009. "Fatigue Risk Management in Aircraft Maintenance." Aviation Today, May 1. Accessed 9 May, 2011. http://www.aviationtoday.com/am/categories/bga/FatigueRiskMan agementinAircraft-Maintenance_31474.html.

Bartlett, F. 1932. Remembering: A Study in Experimental and Social Psychology. Cambridge: Cambridge University Press.

Battelle Memorial Institute. 1998. An Overview of the Scientific Literature concerning Fatigue, Sleep and the Circadian Cycle. Seattle, WA: Battelle Memorial Institute. 
Bennett, S. A. 2003. "Flight Crew Stress and Fatigue in Low-cost Commercial Air Operations - An Appraisal." International Journal of Risk Assessment and Management 4 (2): 207-231.

Bennett, S. A. 2006a. “A Longitudinal Ethnographic Study of Aircrews' Lived Experience of Flying Operations at a Low-cost Airline." Risk Management 8 (2): 92-117.

Bennett, S. A. 2006b. A Sociology of Commercial Flight Crew. Aldershot: Ashgate Publishing.

Bennett, S. A. 2010. "A Longitudinal Ethnographic Study of Night Freight Pilots." Journal of Risk Research 13 (6): 701-730.

Bennett, S. A. 2014. How Pilots Live: An Examination of the Lifestyle of Commercial Pilots. Oxford: Peter Lang International Academic Publishers.

Berger, J., and J. Mohr. 2010. A Seventh Man, a Book of Images and Words about the Experience of Migrant Workers in Europe. London: Verso.

Bogdan, R., and S. J. Taylor. 1975. Introduction to Qualitative Research Methods: A Phenomenological Approach to the Social Sciences. New York: Wiley.

Bolton, G. 2010. Reflective Practice, Writing and Professional Development. 3rd ed. Thousand Oaks, CA: Sage.

Briner, R. B., and P. Totterdell. 2002. "The Experience, Expression and Management of Emotion at Work." In Psychology at Work, edited by Peter Warr, 229-252. London: Penguin.

Bruner, J. S. 1986. Actual Minds, Possible Worlds. Cambridge, MA: Harvard University Press.

Burns, R. B. 2000. Introduction to Research Methods. Thousand Oaks, CA: Sage.

Caldwell, John A., Melissa M. Mallis, J. Lynn Caldwell, Michel A. Paul, James C. Miller, and David F. Neri. 2009. "Fatigue Countermeasures in Aviation." Aviation, Space, and Environmental Medicine 80 (1): 29-59.

Campbell, R. D., and M. Bagshaw. 1999. Human Performance and Limitations in Aviation. Oxford: Blackwell Science.

Charlton, S. G. 2008. "Measurement of Cognitive States in Test and Evaluation." In Handbook of Human Factors Testing and Evaluation, edited by Samuel Charlton and Thomas O’Brien, 97-126. Mahwah, NJ: Lawrence Erlbaum.

Dekker, S. 2007. "Workload: A Strange Concept." Hindsight, July, 6.

Dekker, S. 2014. The Field Guide to Understanding 'Human Error'. 3rd ed. Farnham: Ashgate Publishing.

Dewey, J. 1933. How We Think. A Restatement of the Relation of Reflective Thinking to the Educative Process. Revised ed. Boston, MA: D. C. Heath.

Eurocontrol. 2012. "Workload." Eurocontrol Skybrary. Accessed 28 May, 2012. http://www. skybrary.aero/index.php/Workload_(OGHFA_BN).

Federal Aviation Administration. 2006. Advisory Circular 120-90. Line Operations Safety Audits. Washington, DC: Federal Aviation Administration.

Flight Safety Foundation. 2000. FSF ALAR Briefing Note 7.4 Visual Approaches. Alexandria, VA: Flight Safety Foundation.

Gilbert, N. 1993. Researching Social Life. London: Sage.

Ginnett, R.C. 1990. "Airline Cockpit Crew." In Groups That Work (and Those That Don't): Creating Conditions for Effective Teamwork, edited by J. Richard Hackman, 427-448. San Francisco, CA: Jossey-Bass.

Green, Roger G., Helen Muir, Melanie James, David Gradwell, and Roger L. Green. 1996. Human Factors for Pilots. 2nd ed. Aldershot: Ashgate Publishing.

Haertner, A. 2011. Frauen Im Cockpit: Eine Ethnographische Studie über Weibliche Berufsbilder Und Berufspraxis [Female Pilots: An Ethnographic Study of Female Professional Praxis in a Male Domain]. Leicester: Leicester University Vaughan College.

Hart, S. G., and L. E. Staveland. 1988. "Development of NASA-TLX (Task Load Index): Results of Empirical and Theoretical Research." In Human Mental Workload, edited by Peter A. Hancock and Najmedin Meshkati, 139-183. New York: Elsevier.

Harvey, L., and M. MacDonald. 1993. Doing Sociology. Basingstoke: Macmillan.

Helmreich, R. L., and A. C. Merritt. 1998. Culture at Work in Aviation and Medicine. National, Organizational and Professional Influences. Aldershot: Ashgate Publishing.

Hockey, R. 2002. "Human Performance in the Working Environment." In Psychology at Work, edited by Peter Warr, 26-50. London: Penguin. 
International Civil Aviation Organisation. 2002. Line Operations Safety Audit. Montreal: International Civil Aviation Organisation.

Lee, H. 1960. To Kill a Mockingbird. Philadelphia, PA: J.B. Lippincott.

Lee, K. 2010. Effects of Flight Factors on Pilot Performance, Workload and Stress at Final Approach to Landing Phase of Flight. A Dissertation Submitted in Partial Fulfilment of the Requirements for the Degree of Doctor of Philosophy in the Department of Industrial Engineering and Management Systems in the College of Engineering and Computer Science at the University of Central Florida, Orlando, Florida [Unpublished]. Orlando: University of Central Florida.

Maurino, Daniel E., James Reason, N. Johnston, and Robert B. Lee. 1998. Beyond Aviation Human Factors - Safety in High-technology Systems. Aldershot: Ashgate Publishing.

McAllister, B. 1997. Crew Resource Management. Awareness, Cockpit Efficiency and Safety. Shrewsbury: Airlife.

Morris, C. H., and Y. K. Leung. 2006. "Pilot Mental Workload: How Well Do Pilots Really Perform?" Ergonomics 49 (15): 1581-1596.

National Aeronautics and Space Administration. 2016. NASA TLX: Task Load Index. Accessed 9 May, 2016. http://humansystems.arc.nasa.gov/groups/tlx/.

Perrow, C. 1983. "The Organizational Context of Human Factors Engineering." Administrative Science Quarterly 28 (4): 521-541.

Pickup, Laura, J. Wilson, Sarah Nichols, Stuart Smith. 2005. "A Conceptual Framework of Mental Workload and the Development of a Self-reporting Integrated Workload Scale for Railway Signallers." In Rail Human Factors, edited by John R. Wilson, and Beverley J. Norris, 319-329. Aldershot: Ashgate Publishing.

Powell, David, Mick B. Spencer, David Holland, Elizabeth Broadbent, and Keith J. Petrie. 2007. "Pilot Fatigue in Short-haul Operations: Effects of Number of Sectors, Duty Length, and Time of Day." Aviation, Space, and Environmental Medicine 78 (7): 698-701.

Reason, J. T. 2013. A Life in Error. Farnham: Ashgate Publishing.

Rhodes, W., and V. Gil. 2002. Fatigue Management Guide for Canadian Marine Pilots: A Trainer's Handbook. York: Rhodes and Associates.

Rubio, Susana, Eva Diaz, Jesus Martin, and Jose M. Puente. 2004. "Evaluation of Subjective Mental Workload: A Comparison of SWAT, NASA TLX, and Workload Profile Methods." Applied Psychology 53 (1): 61-86.

Schermerhorn, John, James Hunt, and Richard Osborn. 2005. Organisational Behaviour. 9th ed. New York: John Wiley \& Sons.

Schön, D. 1983. The Reflective Practitioner, How Professionals Think in Action. New York: Basic Books.

Smith, D. 2012. "CRM Series: Workload Management." Accessed 31 May, 2015. http:// www.cfidarren.com/crmworkload.htm.

Vygotsky, L. S., and A. Kozulin. 1986. Thought and Language. Cambridge, MA: MIT Press.

Waterson, P., and K. Catchpole. 2015. "Human Factors in Healthcare: Welcome Progress, but Still Scratching the Surface." BMJ Quality \& Safety Online, 1-5.

Wright, Peter, Steven Pocock, Robert Fields. 1998. "The Prescription and Practice of Work on the Flight Deck." In ECCE9, Ninth European Conference on Cognitive Ergonomics, University of Limerick, Limerick, Eire, 37-42. 


\section{Appendix 1}

\section{Author's flight-deck observations \\ $B H X-N C E-B H X$}

N1 June

Captain

'Short flights like this (two sector days) are relatively easy to manage. Sectors longer than $2.5 \mathrm{~h}$ are where fatigue really shows'

\begin{tabular}{|c|c|c|}
\hline \multirow[b]{2}{*}{ Element } & \multicolumn{2}{|c|}{$\mathrm{SF}$} \\
\hline & Outbound & Inbound \\
\hline $\mathrm{B}-\mathrm{O}$ & 2 & 4 \\
\hline $\mathrm{O}-\mathrm{T}$ & 2 & 4 \\
\hline $\mathrm{T}-\mathrm{T}$ & 2 & 4 \\
\hline \multirow[t]{2}{*}{$\mathrm{T}-\mathrm{O}$} & 3 & 4 \\
\hline & Duty day (DD) & $4 / 5$ \\
\hline \multicolumn{3}{|l|}{ FO } \\
\hline & & \\
\hline Element & Outbound & Inbound \\
\hline $\mathrm{B}-\mathrm{O}$ & 2 & 4 \\
\hline $\mathrm{O}-\mathrm{T}$ & 2 & 4 \\
\hline $\mathrm{T}-\mathrm{T}$ & 4 & 4 \\
\hline \multirow[t]{2}{*}{$\mathrm{T}-\mathrm{O}$} & 4 & 4 \\
\hline & DD & $2 / 6$ \\
\hline
\end{tabular}

The Captain and First Officer (FO) had flown together before. The Captain had not flown to NCE since Autumn, 2014. The flight was given a slot of 14:10z for departing BHX. Pushed back 14:01 on a stated time of departure (STD) of 13:55. Rotated 14:12. Direct routings given. Top of descent (TOD) 15:18. Landed 04L. ${ }^{24}$ Pushed-back 16:39 on a stated time of departure of 16:55. Rotated 16:51. Brakes on 18:52 on a stated time of arrival at BHX of 19:05.

N2 July

Captain

\begin{tabular}{lcc}
\hline & & SF \\
\cline { 2 - 3 } Element & Outbound & Inbound \\
\hline B-O & 4 & 4 \\
O-T & 4 & 4 \\
T-T & 4 & 2 \\
T-O & 4 & 4 \\
& DD & $1 / 3$ \\
\hline
\end{tabular}




\begin{tabular}{lcc}
\hline FO & & \\
\hline & & SF \\
\cline { 2 - 3 } Element & Outbound & Inbound \\
\hline B-O & 4 & $?$ \\
O-T & 4 & $?$ \\
T-T & 4 & 5 \\
T-O & 4 & 5 \\
& DD & $5 / 5$ \\
\hline
\end{tabular}

The Captain and FO had not flown together before. New Standard Operating Procedures (SOPs) in play. The FO was pilot flying (PF) on the outbound leg. Pushed back 13:48z on a STD of 13:55. Rotated 14:00. Reached Top-of-Climb (TOC) 14:25. At 15:08 received confirmation that the flight would land on 22R. Visual approach to be flown. At 15:11 the Captain asked the FO 'Happy to do this?' The FO replied 'Yes.' TOD 15:13. Following a discussion about the approach, at 15:34, the FO handed the approach and landing to the Captain saying: 'Seems like the logical thing to do' ${ }^{25}$ Brakes off 16:51. Brakes on 18:51 on a stated time of arrival (STA) of 19:05.

N3 July

Captain

'Called to work on a day off. Prior three duties all short earlies. Woke early. Agreed to operate BHX-NCE-BHX, but would probably not have operated a route any longer than a BHX-PMI-BHX'

\begin{tabular}{lcc}
\hline & & SF \\
\cline { 2 - 3 } Element & Outbound & Inbound \\
\hline B-O & 4 & $?$ \\
O-T & 4 & 4 \\
T-T & 3 & 4 \\
T-O & 4 & 4 \\
& DD & $4 / 3$ \\
\hline
\end{tabular}

$\mathrm{FO}$

\begin{tabular}{lcc}
\hline & & SF \\
\cline { 2 - 3 } Element & Outbound & Inbound \\
\hline B-O & 3 & 3 \\
O-T & 3 & 3 \\
T-T & 3 & 4 \\
T-O & 3 & 3 \\
& DD & $1 / 2$ \\
\hline
\end{tabular}

The Captain and FO had not flown together before. The Captain was answering a request to do the flight after flying three early departures (hence 4/3). Had it been a longer duty, he said he would have declined the request. The flight-deck carried two additional persons, the author, and a cabin crewmember on a familiarisation flight. Pushed-back 14:31z on a STD of 13:55. Rotated 14:41 and landed 16:25 on a STA of 16:05. Pushed-back 17:20 and parked at 19:19 on a STA of 19:05. 
N4 July

Captain

'Day seven of seven. Earlies onto lates'

\begin{tabular}{lcc}
\hline & & SF \\
\cline { 2 - 3 } Element & Outbound & Inbound \\
\hline B-O & 2 & 3 \\
O-T & 2 & 4 \\
T-T & 3 & 3 \\
T-O & 3 & 2 \\
& DD & $7 / 7$ \\
\hline
\end{tabular}

$\mathrm{FO}$

\begin{tabular}{lcc}
\hline & & SF \\
\cline { 2 - 3 } Element & Outbound & Inbound \\
\hline B-O & 3 & 3 \\
O-T & 3 & 2 \\
T-T & 3 & 3 \\
T-O & 2 & 3 \\
& DD & $1 / 4$ \\
\hline
\end{tabular}

The Captain and FO had flown together before. The Captain had not flown to NCE for $c a .18$ months. The FO had previously flown with the new SOPs, the Captain had not. The FO was PF outbound. Pushed back 13:52z on a STD of 13:55. Rotated 14:05. At 15:21, PF briefed for landing on 04L. At 15:30, ATC instructed PF to land on 22R. Parked 16:12 on a STA of 16:05. Pushed back 16:59 on a STD of 16:55. Parked 18:55 on a STA of 19:05.

N5 July

\begin{tabular}{lcc}
\hline Captain & & \\
\hline & & SF \\
\cline { 2 - 4 } Element & Outbound & Inbound \\
\hline B-O & 4 & 5 \\
O-T & 4 & 5 \\
T-T & 4 & 5 \\
T-O & 4 & 5 \\
& DD & $2 / 3$ \\
\hline
\end{tabular}


$\mathrm{FO}$

'Flight delayed 50 min. CPT called from STBY, therefore late. All pre-despatch work completed by me [FO]. Lots of extra workload, but all manageable'

\begin{tabular}{lcc}
\hline & & SF \\
\cline { 2 - 3 } Element & Outbound & Inbound \\
\hline B-O & 2 & 2 \\
O-T & 2 & 2 \\
T-T & 2 & 2 \\
T-O & 2 & 2 \\
& DD & $2 / 4$ \\
\hline
\end{tabular}

Delays. Aircraft was positioned to BHX from LGW. New Captain called from Standby (SBY). New ground handling at BHX (Aviator). Commenced boarding passengers (PAX) 14:15z. Captain called by Crewing at 13:00. Drove from Worcester in heavy traffic. Captain boarded 14:45. The Captain and FO had flown together previously. Pushed back 14:55 on a STD of 13:55. FO was PF. Rotated 15:08. At 15:11 Captain stated that he had 'caught up'. Landed 04L 16:50. Parked 16:56 on a STA of 16:05. Pushed back 17:49 on a STD of 16:55. Captain briefed that he was 'a little tired'. At 19:11 the Captain (PF) briefed that he was 'tired' and that he'd be descending into BHX 'sharpish'. Landed 19:45 on BHX33 and parked at 19:48 on a STA of 19:05.

N6 September

\begin{tabular}{lcc}
\hline Captain & & \\
\hline & & SF \\
\cline { 2 - 4 } Element & Outbound & Inbound \\
\hline B-O & 2 & 2 \\
O-T & 2 & 2 \\
T-T & 2 & 2 \\
T-O & 2 & 2 \\
& DD & $1 / 0$ \\
\hline
\end{tabular}

$\mathrm{FO}$

\begin{tabular}{lcc}
\hline & & SF \\
\cline { 2 - 4 } Element & Outbound & Inbound \\
\hline B-O & 4 & $?$ \\
O-T & 4 & $?$ \\
T-T & 4 & $?$ \\
T-O & 4 & $?$ \\
& DD & $6 / 6$ \\
\hline
\end{tabular}

Captain called in off SBY. The Captain and FO had not flown together before. One of the two air conditioning packs was inoperative. Weather (Wx) good all day. Pushed back 13:54z on a STD of 13:55. FO flew the outbound leg. Landed 04L 15:47. Parked 15:50 on a STA of 16:05. The flight crew helped the cabin crew clean the aircraft. Pushed back 16:51 on a STD of 16:55. Parked 18:55 on a STA of 19:05. 
N7 October

\begin{tabular}{lcc}
\hline Captain & & \\
\hline & & SF \\
\cline { 2 - 3 } Element & Outbound & Inbound \\
\hline B-O & 3 & 3 \\
O-T & 3 & 3 \\
T-T & 3 & 3 \\
T-O & 3 & 3 \\
& DD & $2 / 2$ \\
\hline
\end{tabular}

FO

\begin{tabular}{lcc}
\hline & & SF \\
\cline { 2 - 3 } Element & Outbound & Inbound \\
\hline B-O & 3 & 3 \\
O-T & 2 & 4 \\
T-T & 3 & 4 \\
T-O & 3 & 4 \\
& DD & $1 / 1$ \\
\hline
\end{tabular}

The Captain and FO had flown together on many occasions. NCE imposed a slot of 14:30z, later moved to 14:20. Pushed back 14:04 and rotated at 14:15 on a STD of 13:55. FO's sector. Thunderstorm activity in vicinity of NCE. Crew discussed alternates at 15:15. The FO briefed for landing at 15:25. Landed 16:07 on 04L in poor weather. Parked 16:14 on a STA of 16:05. Fuel bowser broke down. Replacement summoned. Took some time to arrive. Only one bus available to disembark PAX. Taxied off remote stand 17:26 on a STD of 16:55. UK Wx good. Parked 19:15 on a STA of 19:05. Abusive passenger necessitated police to aircraft.

N8 October

Captain

'Outbound: Busy arrival due bad weather @ NCE. Difficult terrain, but not overworked. Inbound: Overall fatigue level low post 2 sectors. Was well rested before duty. WX @ NCE was challenging, but nothing stressful to deal with on this flight'

\begin{tabular}{lcc}
\hline & & SF \\
\cline { 2 - 3 } Element & Outbound & Inbound \\
\hline B-O & 1 & 1 \\
O-T & 1 & 1 \\
T-T & 1 & 2 \\
T-O & 1 & 3 \\
& DD & $1 / 5$ \\
\hline
\end{tabular}




\begin{tabular}{lcc}
\hline FO & & \\
\hline & & SF \\
\cline { 2 - 4 } Element & Outbound & Inbound \\
\hline B-O & 4 & 3 \\
O-T & 3 & 3 \\
T-T & 2 & 3 \\
T-O & 2 & 3 \\
& DD & $3 / 4$ \\
\hline
\end{tabular}

The Captain and FO had flown together previously. The Captain had not flown for two weeks. Pushed back 13:50z on a STD of 13:55. Captain's leg. Landed 15:43 in heavy rain. Parked 15:50 on a STA of 16:05. Steps to L1 only (left side, main door), slowing disembarkation. Taxied off 16:58 on a STD of 16:55. Parked 19:04 on a STA of 19:05.

N9 October

\begin{tabular}{lcc}
\hline Captain & & \\
\hline & & SF \\
\cline { 2 - 4 } Element & Outbound & Inbound \\
\hline B-O & 4 & 4 \\
O-T & 3 & 4 \\
T-T & 3 & 4 \\
T-O & 4 & 4 \\
& DD & $? / ?$ \\
\hline
\end{tabular}

$\mathrm{FO}$

\begin{tabular}{lcc}
\hline & & SF \\
\cline { 2 - 4 } Element & Outbound & Inbound \\
\hline B-O & 3 & 4 \\
O-T & 3 & 5 \\
T-T & 4 & $?$ \\
T-O & 4 & $?$ \\
& DD & $? / ?$ \\
\hline
\end{tabular}

The Captain and FO had flown together before. However, they had not flown together for some months. FO was PF on first leg. Pushed back 13:47z on a STD of 13:55. TOC 14:18. Briefed for landing 15:00. TOD 15:10. Flight Director command bars cleared at 15:37 for visual approach 04L. Parked 15:45 on a STA of 16:05. Commenced disembarkation 15:52 via L1 only. Doors closed 16:48. Taxied off 16:55 on a STD of 16:55. Rotated 17:03. Briefed for landing 18:16. TOD 18:18. Parked 18:56 on a STA of 19:05. Captain and FO required to position an aircraft to LTN, then position another back to BHX. 
$B H X-P M I-B H X$

P1 June

Captain

'A couple of fringe issues increased workload, especially paperwork-type tasks e.g. manual loadsheet. Slot delay at PMI was a little tiring. PMI-BHX: usual demanding approach into BHX33. High and fast. Manageable, but it requires an above-average level of concentration [Workload MAX and AVERAGE for descent into BHX scored at 4, fatigue scored at 4]'

\begin{tabular}{lcc}
\hline & & SF \\
\cline { 2 - 3 } Element & Outbound & Inbound \\
\hline B-O & 1 & 2 \\
O-T & 1 & 2 \\
T-T & 1 & 2 \\
T-O & 2 & 4 \\
& DD & $1 / ?$ \\
\hline
\end{tabular}

FO

\begin{tabular}{lcc}
\hline & & SF \\
\cline { 2 - 3 } Element & Outbound & Inbound \\
\hline B-O & 2 & 3 \\
O-T & 2 & 4 \\
T-T & 2 & 4 \\
T-O & 2 & 5 \\
& DD & $4 / ?$ \\
\hline
\end{tabular}

On a STD of 13:00z the aircraft rotated at 13:28. The Captain and FO had flown together on half a dozen occasions. Some carriers use electronic load sheets. This carrier uses manual load sheets. This adds to pilots' workload. The carrier plans to introduce electronic flight bags. The flight was given a slot for departing PMI. The FO was not offered his meal until top-of-descent (TOD). He refused it. The flight carried some trainee cabin crew.

P2 June

Captain

'After waking went for run. Showered. Breakfast. Drove to work. Short flight, no fatigue evident'

SF

\begin{tabular}{lcc}
\cline { 2 - 3 } Element & Outbound & Inbound \\
\hline B-O & 3 & 3 \\
O-T & 3 & 3 \\
T-T & 3 & 3 \\
T-O & 3 & 3 \\
& DD & $1 / 4$ \\
\hline
\end{tabular}




\begin{tabular}{lcc}
\hline FO & & \\
\hline & & SF \\
\cline { 2 - 4 } Element & Outbound & Inbound \\
\hline B-O & $?$ & 3 \\
O-T & $?$ & 3 \\
T-T & $?$ & 4 \\
T-O & $?$ & 4 \\
& DD & $3 / 4$ \\
\hline
\end{tabular}

The Captain lived a 90-min drive from BHX. He and the FO had not flown together before (in a Line Operations Safety Audit this fact would be described as a risk). Pushed-back 12:04z on a STD of 11:55. Rotated 12:15. Reached TOC 12:40. Some male passengers were drinking. The Cabin Manager refused one group drinks. Touched down 14:11 and parked 14:16. Pushed-back 15:16, rotated 15:26 and parked at 17:44 on a STA at BHX of 17:55.

P3 July

\begin{tabular}{lcc}
\hline Captain & & \\
\hline & & SF \\
\cline { 2 - 4 } Element & Outbound & Inbound \\
\hline B-O & 3 & 3 \\
O-T & 3 & 3 \\
T-T & 3 & 3 \\
T-O & 3 & 3 \\
& DD & $1 / 5$ \\
\hline
\end{tabular}

$\mathrm{FO}$

\begin{tabular}{lcc}
\hline & & SF \\
\cline { 2 - 3 } Element & Outbound & Inbound \\
\hline B-O & 2 & 3 \\
O-T & 2 & 3 \\
T-T & 2 & 3 \\
T-O & 2 & 4 \\
& DD & $3 / 6$ \\
\hline
\end{tabular}

The Captain and FO had flown together before. Engineering had been doing engine runs due to vibration on engine number 2. Wx overcast with rain. Pushed back 12:08z on a STD of 11:55. Rotated 12:20 and reached TOC at 12:44. The PF's (FO's) map display developed an intermittent fault. Landed 14:28 and parked 14:36 on a STA of 14:25. Problem with one of the doors. Pushed back 15:33 on a STD of 15:15. Parked 17:53 on a STA of 17:55. The crew completed their WorkFat forms (outbound and inbound legs) on the return leg. 


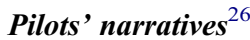

$B H X-N C E-B H X$

NN1

'Called to work on a day off. Prior three duties all short earlies. Woke early. Agreed to operate BHX-NCE-BHX, but would probably not have operated a route any longer than a

BHX-PMI-BHX'

\begin{tabular}{|c|c|c|c|}
\hline \multirow[b]{2}{*}{ Element } & & \multicolumn{2}{|c|}{ SF } \\
\hline & & Outbound & Inbound \\
\hline $\mathrm{B}-\mathrm{O}$ & & 4 & $?$ \\
\hline $\mathrm{O}-\mathrm{T}$ & & 4 & 4 \\
\hline $\mathrm{T}-\mathrm{T}$ & & 3 & 4 \\
\hline $\mathrm{T}-\mathrm{O}$ & & 4 & 4 \\
\hline Month & July & DD & $4 / 3$ \\
\hline
\end{tabular}

NN2

'Day seven of seven. Earlies onto lates'

\begin{tabular}{|c|c|c|c|}
\hline \multirow[b]{2}{*}{ Element } & & \multicolumn{2}{|c|}{ SF } \\
\hline & & Outbound & Inbound \\
\hline $\mathrm{B}-\mathrm{O}$ & & 2 & 3 \\
\hline $\mathrm{O}-\mathrm{T}$ & & 2 & 4 \\
\hline $\mathrm{T}-\mathrm{T}$ & & 3 & 3 \\
\hline $\mathrm{T}-\mathrm{O}$ & & 3 & 2 \\
\hline Month & July & DD & $7 / 7$ \\
\hline
\end{tabular}

NN3

'A 3rd sector assigned after landing. BHX-LGW. Positioning. Workload 4, Fatigue 5'

\begin{tabular}{|c|c|c|c|}
\hline \multirow[b]{2}{*}{ Element } & & \multicolumn{2}{|c|}{ SF } \\
\hline & & Outbound & Inbound \\
\hline $\mathrm{B}-\mathrm{O}$ & & 3 & 4 \\
\hline $\mathrm{O}-\mathrm{T}$ & & 3 & 4 \\
\hline $\mathrm{T}-\mathrm{T}$ & & 3 & $?$ \\
\hline $\mathrm{T}-\mathrm{O}$ & & $?$ & $?$ \\
\hline Month & September & DD & $3 / 5$ \\
\hline
\end{tabular}

NN4

'Too busy to fill this form in on the outbound sector, so I filled it in retrospectively'

\begin{tabular}{|c|c|c|c|}
\hline \multirow[b]{2}{*}{ Element } & & \multicolumn{2}{|c|}{$\mathrm{SF}$} \\
\hline & & Outbound & Inbound \\
\hline $\mathrm{B}-\mathrm{O}$ & & 4 & $?$ \\
\hline $\mathrm{O}-\mathrm{T}$ & & 4 & $?$ \\
\hline $\mathrm{T}-\mathrm{T}$ & & 4 & $?$ \\
\hline $\mathrm{T}-\mathrm{O}$ & & 4 & $?$ \\
\hline Month & September & DD & $6 / 6$ \\
\hline
\end{tabular}


$B H X-P M I-B H X$

PN1

'After waking went for run. Showered. Breakfast. Drove to work. Short flight, no fatigue evident'

\begin{tabular}{|c|c|c|c|}
\hline \multirow[b]{2}{*}{ Element } & & \multicolumn{2}{|c|}{ SF } \\
\hline & & Outbound & Inbound \\
\hline $\mathrm{B}-\mathrm{O}$ & & 3 & 3 \\
\hline $\mathrm{O}-\mathrm{T}$ & & 3 & 3 \\
\hline $\mathrm{T}-\mathrm{T}$ & & 3 & 3 \\
\hline $\mathrm{T}-\mathrm{O}$ & & 3 & 3 \\
\hline Month & June & DD & $1 / 4$ \\
\hline
\end{tabular}

PN2

'Very early alarm woke me from a good sleep. Felt below-par on the drive to work, but gradually "got going". Did not feel $100 \%$ until reaching PMI. Felt tired half way home, but still lively"

\begin{tabular}{|c|c|c|c|}
\hline \multirow[b]{2}{*}{ Element } & & \multicolumn{2}{|c|}{ SF } \\
\hline & & Outbound & Inbound \\
\hline $\mathrm{B}-\mathrm{O}$ & & 3 & 1 \\
\hline $\mathrm{O}-\mathrm{T}$ & & 3 & 1 \\
\hline $\mathrm{T}-\mathrm{T}$ & & 2 & 1 \\
\hline $\mathrm{T}-\mathrm{O}$ & & 2 & 2 \\
\hline Month & June & DD & $4 / ?$ \\
\hline
\end{tabular}

PN3

'Yesterday was very tiring. Roster is LGW for two earlies. Early Dalaman, then LGW-PMI. Back to BHX straight afterwards, to do three more earlies. Waking up between 03:00 and 04:00 to report on-time for each. I was rostered BHX-DLM today (day three of five) but spoke to crewing to move to a shorter flight at least. Still unsure whether I will be able to manage all five earlies. Generally getting six hours sleep each night, so after five I am in ten hours sleep debt. Always feel a low on return sector of an early start. I struggle to keep my eyes open. I made a lot of stupid mistakes yesterday, saying the wrong words, or just doing the wrong thing'

\begin{tabular}{|c|c|c|c|}
\hline \multirow[b]{2}{*}{ Element } & & \multicolumn{2}{|c|}{$\mathrm{SF}$} \\
\hline & & Outbound & Inbound \\
\hline B-O & & 4 & 5 \\
\hline $\mathrm{O}-\mathrm{T}$ & & 4 & 5 \\
\hline $\mathrm{T}-\mathrm{T}$ & & 4 & 5 \\
\hline $\mathrm{T}-\mathrm{O}$ & & 4 & 5 \\
\hline Month & June & DD & $3 / 5$ \\
\hline
\end{tabular}


PN4

'More tired than usual. Am having to double-check actions. Day six, of six earlies. Very early departures [woke at 01:55z for scheduled 05:10z departure]'

\begin{tabular}{|c|c|c|c|}
\hline \multirow[b]{2}{*}{ Element } & & \multicolumn{2}{|c|}{ SF } \\
\hline & & Outbound & Inbound \\
\hline $\mathrm{B}-\mathrm{O}$ & & $?$ & 5 \\
\hline $\mathrm{O}-\mathrm{T}$ & & $?$ & 5 \\
\hline $\mathrm{T}-\mathrm{T}$ & & ? & 5 \\
\hline $\mathrm{T}-\mathrm{O}$ & & $?$ & 5 \\
\hline Month & June & DD & $6 / 6$ \\
\hline
\end{tabular}

PN5

'Taxi from MAN to BHX prior to flight'

\begin{tabular}{|c|c|c|c|}
\hline \multirow[b]{2}{*}{ Element } & & \multicolumn{2}{|c|}{$\mathrm{SF}$} \\
\hline & & Outbound & Inbound \\
\hline $\mathrm{B}-\mathrm{O}$ & & 1 & 2 \\
\hline $\mathrm{O}-\mathrm{T}$ & & 1 & 2 \\
\hline $\mathrm{T}-\mathrm{T}$ & & 2 & 2 \\
\hline $\mathrm{T}-\mathrm{O}$ & & 2 & 4 \\
\hline Month & June & DD & $1 / 5$ \\
\hline
\end{tabular}

PN6

'Long drive to BHX, followed by four very early morning departures, and drive back to LGW (145 min), plus 30 miles further to get home. Numerous programme changes. Very fatiguing'

\begin{tabular}{|c|c|c|c|}
\hline \multirow[b]{2}{*}{ Element } & & \multicolumn{2}{|c|}{$\mathrm{SF}$} \\
\hline & & Outbound & Inbound \\
\hline B-O & & 5 & 5 \\
\hline $\mathrm{O}-\mathrm{T}$ & & 5 & 5 \\
\hline $\mathrm{T}-\mathrm{T}$ & & 5 & 5 \\
\hline $\mathrm{T}-\mathrm{O}$ & & 5 & 5 \\
\hline Month & June & DD & $5 / 5$ \\
\hline
\end{tabular}

PN7

'First flight after early standby. Poor sleep due to the hot weather, and not acclimatised to early duties'

\begin{tabular}{|c|c|c|c|}
\hline \multirow[b]{2}{*}{ Element } & & \multicolumn{2}{|c|}{ SF } \\
\hline & & Outbound & Inbound \\
\hline $\mathrm{B}-\mathrm{O}$ & & 5 & 5 \\
\hline $\mathrm{O}-\mathrm{T}$ & & 5 & 5 \\
\hline $\mathrm{T}-\mathrm{T}$ & & 5 & 5 \\
\hline $\mathrm{T}-\mathrm{O}$ & & 5 & 6 \\
\hline Month & July & DD & $2 / 5$ \\
\hline
\end{tabular}


PN8

'No time to update WorkFat during boarding regarding to OTP [on-time performance]'

\begin{tabular}{|c|c|c|c|}
\hline \multirow[b]{2}{*}{ Element } & & \multicolumn{2}{|c|}{ SF } \\
\hline & & Outbound & Inbound \\
\hline $\mathrm{B}-\mathrm{O}$ & & 3 & 3 \\
\hline $\mathrm{O}-\mathrm{T}$ & & 3 & 4 \\
\hline $\mathrm{T}-\mathrm{T}$ & & 3 & 4 \\
\hline $\mathrm{T}-\mathrm{O}$ & & 3 & 5 \\
\hline Month & July & DD & $2 / 2$ \\
\hline
\end{tabular}

PN9

'First flight of run was 03:50 PMI. Second, 13:50 TFS [Tenerife]. Today, night PMI. No sleep during the day'

\begin{tabular}{|c|c|c|c|}
\hline \multirow[b]{2}{*}{ Element } & & \multicolumn{2}{|c|}{$\mathrm{SF}$} \\
\hline & & Outbound & Inbound \\
\hline $\mathrm{B}-\mathrm{O}$ & & 5 & $?$ \\
\hline $\mathrm{O}-\mathrm{T}$ & & 5 & ? \\
\hline $\mathrm{T}-\mathrm{T}$ & & 5 & $?$ \\
\hline $\mathrm{T}-\mathrm{O}$ & & 5 & ? \\
\hline Month & July & DD & $3 / 4$ \\
\hline
\end{tabular}

PN10

'Please note that flight on day four of four is SSH [Sharm El Sheik], so very long day. Anticipating waking early, due to previous three days of earlies, up at around 03:00z. Expecting to be very tired indeed for the drive home'

\begin{tabular}{|c|c|c|c|}
\hline \multirow[b]{2}{*}{ Element } & & \multicolumn{2}{|c|}{$\mathrm{SF}$} \\
\hline & & Outbound & Inbound \\
\hline $\mathrm{B}-\mathrm{O}$ & & 2 & 4 \\
\hline $\mathrm{O}-\mathrm{T}$ & & 4 & 5 \\
\hline $\mathrm{T}-\mathrm{T}$ & & 4 & 5 \\
\hline $\mathrm{T}-\mathrm{O}$ & & 3 & 4 \\
\hline Month & July & DD & $3 / 4$ \\
\hline
\end{tabular}

\section{PN11}

'Woke at 07:30; napped from 17:00z until 18:45z. Went to bed at 02:30z previous night [Night BHX-PMI-BHX departing 21:35z]'

\begin{tabular}{|c|c|c|c|}
\hline \multirow[b]{2}{*}{ Element } & & \multicolumn{2}{|c|}{ SF } \\
\hline & & Outbound & Inbound \\
\hline $\mathrm{B}-\mathrm{O}$ & & 1 & 2 \\
\hline $\mathrm{O}-\mathrm{T}$ & & 1 & 2 \\
\hline $\mathrm{T}-\mathrm{T}$ & & 1 & 2 \\
\hline $\mathrm{T}-\mathrm{O}$ & & 1 & $?$ \\
\hline Month & July & DD & $5 / 6$ \\
\hline
\end{tabular}


PN12

'Back to sleep at 13:00z. Woke at 16:00z [Night BHX-PMI-BHX departing 21:35z]'

\begin{tabular}{|c|c|c|c|}
\hline \multirow[b]{2}{*}{ Element } & & \multicolumn{2}{|c|}{ SF } \\
\hline & & Outbound & Inbound \\
\hline $\mathrm{B}-\mathrm{O}$ & & 3 & 3 \\
\hline $\mathrm{O}-\mathrm{T}$ & & 3 & 4 \\
\hline $\mathrm{T}-\mathrm{T}$ & & 3 & 4 \\
\hline $\mathrm{T}-\mathrm{O}$ & & 3 & 4 \\
\hline Month & July & DD & $5 / 5$ \\
\hline
\end{tabular}

PN13

'Fifth very early report in a row. Woke up on alarm at 03:30z. The day before at Madeira had been challenging. Felt OK, so decided to operate the flight. Cumulative fatigue kicking in as flight progressed. Nothing missed, but had to confirm calls and checks, as could not remember if done'

\begin{tabular}{|c|c|c|c|}
\hline \multirow[b]{2}{*}{ Element } & & \multicolumn{2}{|c|}{ SF } \\
\hline & & Outbound & Inbound \\
\hline $\mathrm{B}-\mathrm{O}$ & & 4 & 5 \\
\hline $\mathrm{O}-\mathrm{T}$ & & 4 & 5 \\
\hline $\mathrm{T}-\mathrm{T}$ & & 4 & 6 \\
\hline $\mathrm{T}-\mathrm{O}$ & & 5 & 6 \\
\hline Month & July & DD & $6 / 6$ \\
\hline
\end{tabular}

PN14

'A/C had tech fault out of BHX (APU inop). Therefore warm. No tea-making facilities for morning tea (caffeine). Prolonged start process. A/C had tech fault at PMI (APU inop).

Extended start procedure required. Hot. However, external air con worked really well to cool cabin and mitigate fatigue'

\begin{tabular}{|c|c|c|c|}
\hline \multirow[b]{2}{*}{ Element } & & \multicolumn{2}{|c|}{ SF } \\
\hline & & Outbound & Inbound \\
\hline $\mathrm{B}-\mathrm{O}$ & & 3 & 3 \\
\hline $\mathrm{O}-\mathrm{T}$ & & 3 & 3 \\
\hline $\mathrm{T}-\mathrm{T}$ & & 2 & 3 \\
\hline $\mathrm{T}-\mathrm{O}$ & & 2 & 3 \\
\hline Month & July & DD & $5 / 6$ \\
\hline
\end{tabular}

PN15

'Run of five earlies, now five lates (one disruption day between early run and late run) .... Feeling tired due to rostering'

\begin{tabular}{|c|c|c|c|}
\hline \multirow[b]{2}{*}{ Element } & & \multicolumn{2}{|c|}{$\mathrm{SF}$} \\
\hline & & Outbound & Inbound \\
\hline $\mathrm{B}-\mathrm{O}$ & & 5 & 5 \\
\hline $\mathrm{O}-\mathrm{T}$ & & 5 & 5 \\
\hline $\mathrm{T}-\mathrm{T}$ & & 5 & 5 \\
\hline $\mathrm{T}-\mathrm{O}$ & & 5 & 5 \\
\hline Month & July & DD & $5 / 5$ \\
\hline
\end{tabular}


PN16

'Previous day agreed to bring duty forward to operate 04:45z AGP [Malaga]. Arrived early. Swapped onto a TFS [Tenerife] to cover crew shortage. Finished 15:15z'

\begin{tabular}{|c|c|c|c|}
\hline \multirow[b]{2}{*}{ Element } & & \multicolumn{2}{|c|}{ SF } \\
\hline & & Outbound & Inbound \\
\hline $\mathrm{B}-\mathrm{O}$ & & 5 & 4 \\
\hline $\mathrm{O}-\mathrm{T}$ & & 5 & 4 \\
\hline $\mathrm{T}-\mathrm{T}$ & & 5 & 5 \\
\hline $\mathrm{T}-\mathrm{O}$ & & 4 & 5 \\
\hline Month & July & DD & $2 / 5$ \\
\hline
\end{tabular}

PN17

'Slots out of BHX. One hour delay. Shortened to $30 \mathrm{~min}$ '

\begin{tabular}{|c|c|c|c|}
\hline \multirow[b]{2}{*}{ Element } & & \multicolumn{2}{|c|}{ SF } \\
\hline & & Outbound & Inbound \\
\hline B-O & & 6 & 5 \\
\hline $\mathrm{O}-\mathrm{T}$ & & 5 & 5 \\
\hline $\mathrm{T}-\mathrm{T}$ & & 5 & 5 \\
\hline $\mathrm{T}-\mathrm{O}$ & & 5 & 6 \\
\hline Month & July & DD & $5 / 5$ \\
\hline
\end{tabular}

PN18

'Slot out of EGBB. PMI extremely busy. G/S was U/S. Slot out of PMI. Non-standard departure. Increased workload'

\begin{tabular}{|c|c|c|c|}
\hline \multirow[b]{2}{*}{ Element } & & \multicolumn{2}{|c|}{ SF } \\
\hline & & Outbound & Inbound \\
\hline $\mathrm{B}-\mathrm{O}$ & & 4 & 4 \\
\hline $\mathrm{O}-\mathrm{T}$ & & 4 & 5 \\
\hline $\mathrm{T}-\mathrm{T}$ & & 4 & 6 \\
\hline $\mathrm{T}-\mathrm{O}$ & & 4 & 6 \\
\hline Month & September & DD & $3 / 6$ \\
\hline
\end{tabular}

PN19

'Previous flight to Canaries that landed 23:00z night before. Obviously, 2 lots of eight hour sleep not possible'

\begin{tabular}{|c|c|c|c|}
\hline \multirow[b]{2}{*}{ Element } & & \multicolumn{2}{|c|}{ SF } \\
\hline & & Outbound & Inbound \\
\hline $\mathrm{B}-\mathrm{O}$ & & 4 & 5 \\
\hline $\mathrm{O}-\mathrm{T}$ & & 4 & 4 \\
\hline $\mathrm{T}-\mathrm{T}$ & & 4 & 5 \\
\hline $\mathrm{T}-\mathrm{O}$ & & 3 & 5 \\
\hline Month & September & DD & $4 / 4$ \\
\hline
\end{tabular}


PN20

'Waking up at 03:20 local is very difficult, and getting sufficient rest for such an early start is extremely hard to do'

\begin{tabular}{|c|c|c|c|}
\hline \multirow[b]{2}{*}{ Element } & & \multicolumn{2}{|c|}{ SF } \\
\hline & & Outbound & Inbound \\
\hline $\mathrm{B}-\mathrm{O}$ & & 5 & $?$ \\
\hline $\mathrm{O}-\mathrm{T}$ & & 5 & ? \\
\hline $\mathrm{T}-\mathrm{T}$ & & 4 & $?$ \\
\hline $\mathrm{T}-\mathrm{O}$ & & 5 & $?$ \\
\hline Month & September & DD & $3 / 5$ \\
\hline
\end{tabular}

PN21

'Both sectors: good weather, no tech issues, no slots'

\begin{tabular}{|c|c|c|c|}
\hline \multirow[b]{2}{*}{ Element } & & \multicolumn{2}{|c|}{ SF } \\
\hline & & Outbound & Inbound \\
\hline $\mathrm{B}-\mathrm{O}$ & & 1 & 1 \\
\hline $\mathrm{O}-\mathrm{T}$ & & 1 & 1 \\
\hline $\mathrm{T}-\mathrm{T}$ & & 2 & 2 \\
\hline $\mathrm{T}-\mathrm{O}$ & & 1 & 1 \\
\hline Month & September & DD & $2 / 3$ \\
\hline
\end{tabular}

PN22

'Night PMI - always tiring [woke 07:00z]'

\begin{tabular}{lccc}
\hline & & SF \\
\cline { 2 - 4 } Element & Outbound & Inbound \\
\hline B-O & $?$ & 6 \\
O-T & $?$ & 6 \\
T-T & $?$ & 6 \\
T-O & September & DD & 6 \\
Month & & $2 / 2$ \\
\hline
\end{tabular}

PN23

'General fatigue setting in now. Days off barely recovering to normal. Starting the working week jaded. Everyone I fly with is tired, and is now a normal part of every briefing [assume part of TEM brief] (07 October 2015)'

\begin{tabular}{|c|c|c|c|}
\hline \multirow[b]{2}{*}{ Element } & & \multicolumn{2}{|c|}{ SF } \\
\hline & & Outbound & Inbound \\
\hline $\mathrm{B}-\mathrm{O}$ & & 5 & 5 \\
\hline $\mathrm{O}-\mathrm{T}$ & & 5 & 5 \\
\hline $\mathrm{T}-\mathrm{T}$ & & 5 & 6 \\
\hline $\mathrm{T}-\mathrm{O}$ & & 5 & 6 \\
\hline Month & October & DD & $3 / 5$ \\
\hline
\end{tabular}


PN24

'Day 4. After alternating early start (no start standby), feel punch-drunk as sleep-pattern disrupted. Relentless early starts, with just two days to recover, have taken their toll. Unlike the start of the Season, body has stopped adjusting quickly'

\begin{tabular}{lccc}
\hline & & SF \\
\cline { 3 - 4 } Element & Outbound & Inbound \\
\hline B-O & 5 & 5 \\
O-T & 5 & 5 \\
T-T & 5 & 6 \\
T-O & 5 & 6 \\
Month & October & DD & $4 / 4$ \\
\hline
\end{tabular}

